\title{
Retalhos de uma pnêumica
}

\section{Patchwork of a Spirituality}

\section{Resu mo}

O artigo em forma de ensaio analisa os 11 segmentos do filme 11'09"01, produzido por Alain Brigand em 2002. Esses segmentos foram feitos por 11 diretores de países diferentes. Todos eles tiveram liberdade para criar curtas-metragens alusivos ao ataque sofrido pelas torres gêmeas do Trade World Center em 11 de setembro de 2001. Havia, no entanto, uma exigência: cada segmento deveria ter onze minutos, nove segundos e um quadro. Neste ensaio esses segmentos são comentados a partir de uma noção específica de espiritualidade corpórea. Essa perspectiva antropológica, nomeada corpoética, entende a espiritualidade como pnêumica - uma respiração revestida pelos signos simbólicos, traduzindo desejos; uma respiração segunda, culturalmente reinventada. Não redutível à religião, a pnêumica corpoética é uma experiência e uma experimentação que parte da materialidade somática, passa por sua historicidade sócio-psíquica e se constitui como inventividade simbólica carregada de sentido/sentimento existencial mais pleno possível. De cada segmento do 11'09"01, uma cena é escolhida para análise e comentário. Essa cena é reproduzida como objeto empírico para o exercício corpoético do enxergar neurofisiológico, do olhar epistêmico e do ver pnêumico. Nesse último se encontra o foco principal deste ensaio sobre uma pnêumica como espiritualidade corpoética.

Palavras-chave: 11'09"01. Ataques terroristas. Corpoética. Espiritualidade.

\section{Abstract}

The in the form of an essay analyzes the 11 segments of the film 11'09"01, produced by Alain Brigand in 2002. These segments were made by 11 directors from different countries. All of them were free to create short films alluding to the attack suffered by the twin towers of the Trade World Center on September 11, 2001. There was, however, one requirement: each segment should last eleven minutes, nine seconds and one frame. In this essay, these segments are commented upon from a specific notion of corporeal spirituality. This anthropological perspective, called "corpoética", understands spirituality as "pneumics" - a breath coated by the symbolic signs, translating desires; a second breath, culturally reinvented. Not reducible to religion, the "pneumics corpoética" is an experience and an experimentation that starts from the somatic materiality, goes through its socio-psychic historicity, and constitutes itself as symbolic inventiveness loaded with the fullest existential meaning/feeling possible. From each segment of the $11^{\prime} 09^{\prime \prime} 01$, a scene is chosen for analysis and commentary. This scene is reproduced as an empirical object for the "corpoético" exercise of neurophysiological seeing, epistemic looking and pneumics gaze. In this latter, lies the main focus of this essay on a pneumics as a "corpoética" spirituality.

Keywords: 11'09"01. Terrorist attacks. "Corpoética". Spirituality. 


\title{
In trod ução
}

\begin{abstract}
Então o homem, flagelado e rebelde, corria diante da fatalidade das coisas, atrás de uma figura nebulosa e esquiva, feita de retalhos, um retalho de impalpável, outro de improvável, outro de invisível, cosidos todos a ponto precário, com a agulha da imaginação; e essa figura - nada menos que a quimera da felicidade - ou lhe fugia perpetuamente, ou deixava-se apanhar pela fralda, e o homem a cingia ao peito, e então ela ria, como um escárnio, e sumia-se, como uma ilusão (Machado de Assis).
\end{abstract}

\section{Pano de fundo}

Texturas econômicas, políticas e culturais alinham-se como tecidos da sociedade. Nisso, o variado prevalece. Daí as justaposições, oposições ou composições dos novelos históricos e suas novelas. Assim, as pessoas se dão o direito, o dever e o desfrute de encontrar um fio pra tanta meada.

Na própria realidade intrínseca das coisas, dos casos e dos causos movem-se os núcleos desordenados e disponíveis dos jogos descritivos e interpretativos. Um fato (ou um fenômeno), por si portador de incertezas e indeterminações, serve à beça para exercícios filosóficos, científicos e estéticos. E quem há de negar quanto os atentados às Torres Gêmeas de Nova lorque em 11/9/2001 estão até hoje edificando e destruindo teorias, hipóteses e artes?

Já em 2002 o produtor francês Alain Brigand conseguiu concretizar a ideia de um filme² composto por 11 curtas-metragens, dirigidos por 11 diretores (adiante devidamente nomeados) de 11 países diferentes. Com um orçamento de US\$ 400.000, cada diretor fez um pequeno filme de 11 minutos, nove segundos e um quadro (11'09"01) sobre o ataque às Torres Gêmeas.

A respeito desses 11 curtas-metragens, este artigo (com estampa de ensaio) borda comentários ligeiros seguindo um molde hermenêutico decalcado da pnêumica - uma espiritualidade corpoética (Lima Júnior, 2013). A propósito, bem lacônico, reproduzo critérios e métodos desse paradigma.

O que não passa pelo corpo não seria espiritual. O templo a consagrar tudo é a corporeidade humana. Portanto, pnêumica referir-se-ia à espiritualidade corpoética, não redutível às espiritualidades religiosas. Quiçá por essas transita e delas, às vezes, se vale nas entrelinhas. Noutras palavras, pnêumica ventila sobre uma respiração revestida pelo simbólico, traduzindo desejo; cogita uma respiração segunda, culturalmente reinventada.

Servindo-me da tipologia semiótica peirceana dos signos (ícone, índice e símbolo), acho cabível certa correspondência à modalidade transtópica da corpoética no tema das perspectivas. A representação (por semelhança) do ícone afeta o somático do enxergar; a representação (por nexo de causa e efeito) do índice conecta o psíquico do olhar e a representação (por arbitrariedade convencional) do símbolo projeta o pnêumico do ver.

Próximo a flashes, explicito: a captação sensória do enxergar usa um sentido estético (predomínio do somático neurofisiológico); a interpretação sócio-psíquica do olhar combina um sentido epistêmico (tensionamento do cultural-histórico) e a imaginação metafísica do ver inventa um sentido catártico (criatividade do pnêumico).

De forma ainda mais sucinta, explano: pressupondo que tudo seja dinamicamente situado, há um complexo movimento cuja objetividade do enxergar (soma), na prevalência do ícone, aponte para a

\footnotetext{
2 O filme 11'09"01, produzido por Galatée Films e Studiocanal (2002), é colorido e tem duração de 128 minutos. Foi distribuído no Brasil em formado DVD pela Europa Filmes (Barueri, São Paulo, 2003, código de barras 7 897119441892) com o título 11 de Setembro.
} 
matéria; cuja subjetividade do olhar (psiquê), na preponderância do índice, apure a memória; e, ainda, cuja afetividade do ver (pnêuma), na primazia do símbolo, avente a mística.

Por óbvio, considerando os objetivos deste número da revista Reflexão - um dossiê/debate 20 anos depois daquele inesquecível 11 de setembro - busco privilegiar uma perspectiva pnêumica na recepção do filme 11'09"01. E, ao assim fazer, procuro articular às outras perspectivas.

Em tempo, assumo a irredutibilidade corpórea do ver a partir do olhar e do enxergar. Esse feitio próprio e estreito, no limite do bom ânimo de quem vier a ler este ensaio, escora a torcida por um mínimo denominador nas frações das ciências sobre os fenômenos espirituais. A conferir.

Sendo mais específico, cada curta-metragem será discutida isoladamente. Assim: depois de uma sinopse interessada e tendenciosa, derramando spoiler, será escolhida, capturada e reproduzida uma cena para comentar. O comentário terá como foco a noção da espiritualidade corpoética depreendida/ atribuída desde uma específica substância fílmica. Ou seja: será oferecida uma brevíssima opinião acerca da pnêumica que noto em alguma cena compartilhada. Com certeza o quadro destacado não esgota uma análise necessária mais exaustiva sobre os 11 minutos da referida montagem (por isso, antecipo um pedido de escusas). O parecer dado deverá apenas funcionar como exíguo realce perscrutador de um fiapo do retalho.

Ganhador do Prêmio da UNESCO no Festival de Veneza de 2002, o filme 11'09"01 ostenta uma fortuna crítica bastante irreconciliável. Muito dessa discordância perpassa principalmente as desencontradas avaliações quanto ao conteúdo de cada uma das onze peças. Pouco se encontra de apreciação que tome a estrita e rigorosa linguagem cinematográfica como ponto de partida. Neste artigo, tanto quanto for possível, vou tomar distância daquela maioria e me juntar ao bocado que aposta na consideração da forma como imprescindível na expressão fílmica dos 11 episódios. Professo que a forma como meio subserviente para o conteúdo não é defensável e julgo que o conteúdo precisa ser testado na própria forma.

Ao final do artigo os retalhos do 11'09"01 serão agrupados num patchwork pnêumico. Mal comparando, se os cartazes de divulgação desse filme aproveitam o design das famosas Torres Gêmeas (em pé ou abatidas) numa colagem de 11 fotos nítidas dos 11 curtas-metragens, opto hic et nunc por algo distinto. O figurativo liso, limpo e elegante será trocado por toscos mosaicos sobrepostos. Pnêumica condensada, conceitual e confusa.

\section{Retalho do Irã}

Samira Makhmalbaf nascida em 1980, a mais jovem dentre os 11 diretores, é uma ativista dos direitos das mulheres. O neorrealismo de seu segmento neste $11^{\prime} 09^{\prime \prime} 01$ poderia ter como tema Deus cria e mata - uma espécie de teologia abordada ingenuamente pelas crianças afegãs refugiadas na proximidade de uma olaria iraniana.

Desde uma cisterna que lembra as fronteiras últimas de um útero vai saindo um cordão umbilical. Um balde d'água vem à luz. Parto perto do pardo para a produção de tijolos destinados à construção de casas e abrigos antiaéreos. Há na comunidade um temor: algum ataque norte-americano aos afegãos.

Pés e mãos de crianças participam da feitura de tijolos enquanto esperam a passagem da professora a convoca-las para a sala de aula. A presença segura e contida da professora contrasta com a exuberância infantil - irrequieta e inocente. Questões religiosas e morais atravessam e descentram o objetivo da 
jovem mestra: falar e sensibilizar a garotada sobre a queda das Torres Gêmeas naquela manhã. E se os alunos não conseguem conceber o que foram as Torres Gêmeas e sua tragédia, pouco importa a essa turminha guardar um minuto de silêncio em memória respeitosa às vítimas. A professora decide, então, levar a classe até perto da grande chaminé da olaria. Quem sabe, a chaminé funcione como derradeiro (e minguado) recurso comparativo aos arranha-céus de Nova lorque. Então, junto à chaminé, volta a chamada pelo minuto de silêncio. E como resposta à indagação do pequeno Esmat ("O que a gente faz se quiser falar?"), a professora pontifica: "Morda os lábios e olhe pra chaminé!" (11 de setembro, 2002, 10'05") (Foto 1).

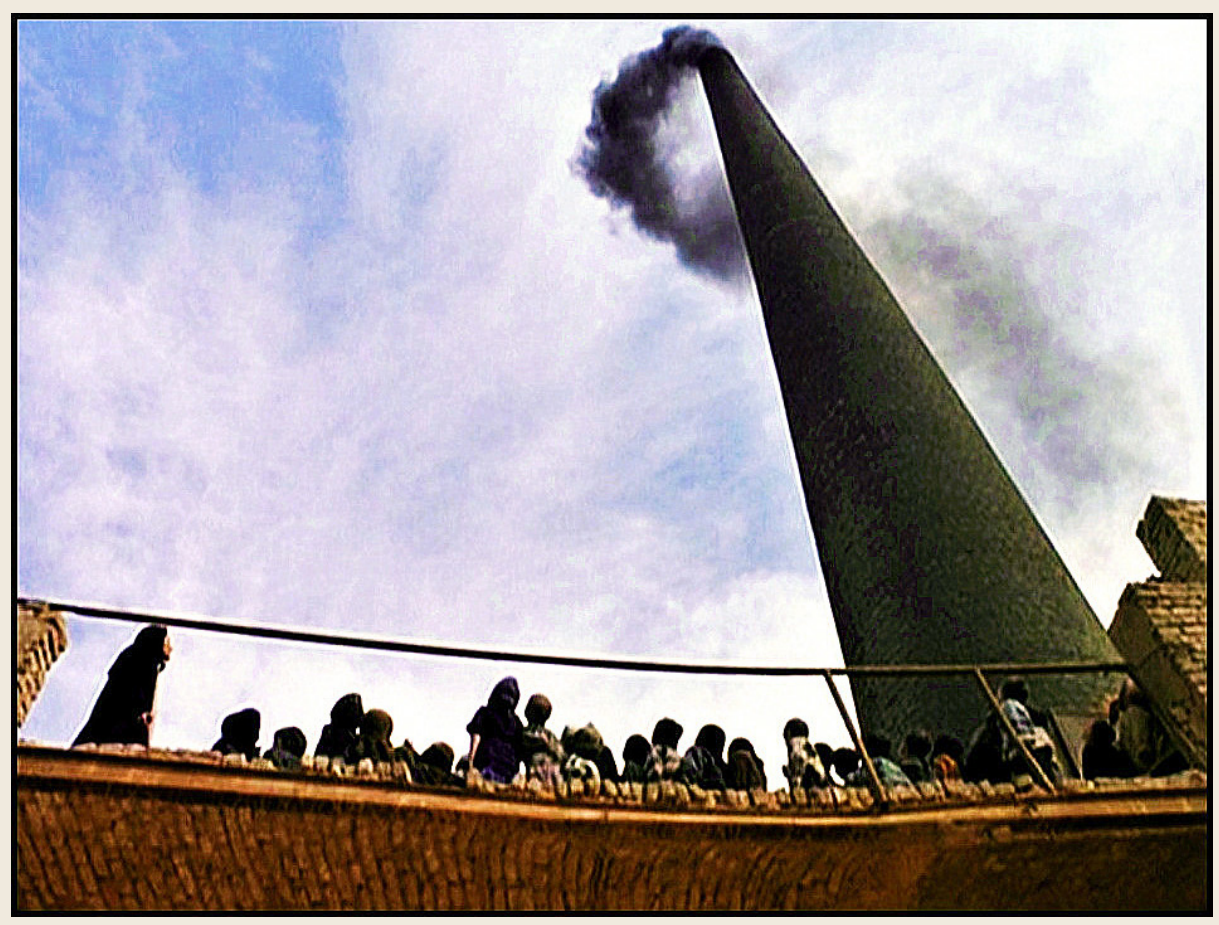

Foto 1 - Retalho do Irã

Fonte: Imagem capturada do filme 11'09"01' (2002).

Essa foto é quase a última imagem (10'25") desse curta-metragem. Posso enxergar uma grande chaminé jogando fumaça no ar, muitas crianças (sobre uma ponte) olhando para cima e uma mulher voltada para a direita. Também consigo olhar como a câmera se postou num plano bem abaixo. Certamente foi usada alguma lente grande-angular que distorceu muito a chaminé e a mulher.

Com uma leitura da imagem fazendo o percurso do enxergar/olhar da direita para a esquerda (seguindo a maneira como se escreve e se lê o idioma persa) ainda invento um ver fabuloso, ficcional, pnêumico. Assim, uma atribuição de sentido mais metafísico parte do fator econômico, com suas técnicas de produção, atravessa o mistério da infância sem dominá-lo e chega aos projetos e programas da educação. As balizas estabelecidas nas extremidades soltam e solam contradições complementares na história: poluição e palavra, pretérito e porvir. Em meio a toda essa tensão, transpiram e transitam anarquicamente crianças que, assim como o vento, surpreendem de onde chegam e disfarçam pra onde caminham. Pnêumica da aposta naquilo que espanta a fumaça e espalha a poesia. 


\section{Retalho da França}

Claude Lelouch nascido em 1937 é o cineasta que mais filmes dirigiu dentro do grupo dos que produziram o material que compõe o 11'09"01. Seu curta-metragem sinaliza uma elegia ao silêncio. Praticamente todo sem som, conta a estória de uma fotógrafa francesa surda-muda morando em Nova Iorque com seu namorado Jérôme, guia turístico, que se especializara em excursões para pessoas surdas. Decorrido algum tempo, a convivência se tornara desgastante e terminal.

Logo pela manhã do dia 11 de setembro de 2001, Jérôme sai para atender a um grupo de turistas que o aguardam em frente ao World Trade Center. Ela fica no apartamento e começa a digitar no computador uma mensagem de despedida para o namorado. Conta suas alegrias e angústias desde quando se conheceram. Critica aspectos da realidade norte-americana com seu culto ao sucesso e à perfeição. Uma frase que esquecera e que naquela manhã voltou com toda intensidade sintetiza o balanço do desencontro: "a gente se dá conta da felicidade quando ela já foi embora".

Na noite anterior haviam discutido e brigado. Jérôme ficou no sofá e ela na cama sob um quadro com a palavra DREAM grafada com letras que diminuíam de tamanho, evocando uma desilusão in progress. Durante a madrugada, inclusive, ela fotografou Jérôme dormindo e o silêncio foi quebrado pelo flash da câmera, porém Jérôme não reagiu ao estímulo.

Quando está para digitar o fim da mensagem, ela percebe o sinal luminoso da chegada de alguém à porta de entrada do apartamento. Vai abrir e encontra Jérôme coberto de poeira, visivelmente abalado. Chocada com o imprevisto, pede explicações. Jérôme sorri quase chorando e pergunta se ela não acompanhara o que a TV estava informando em tempo real: a queda das Torres Gêmeas. Daí nada mais restou senão a ternura de um afago-que-tudo-releva a sugerir a sobrevivência de ambos como casal (Foto 2).

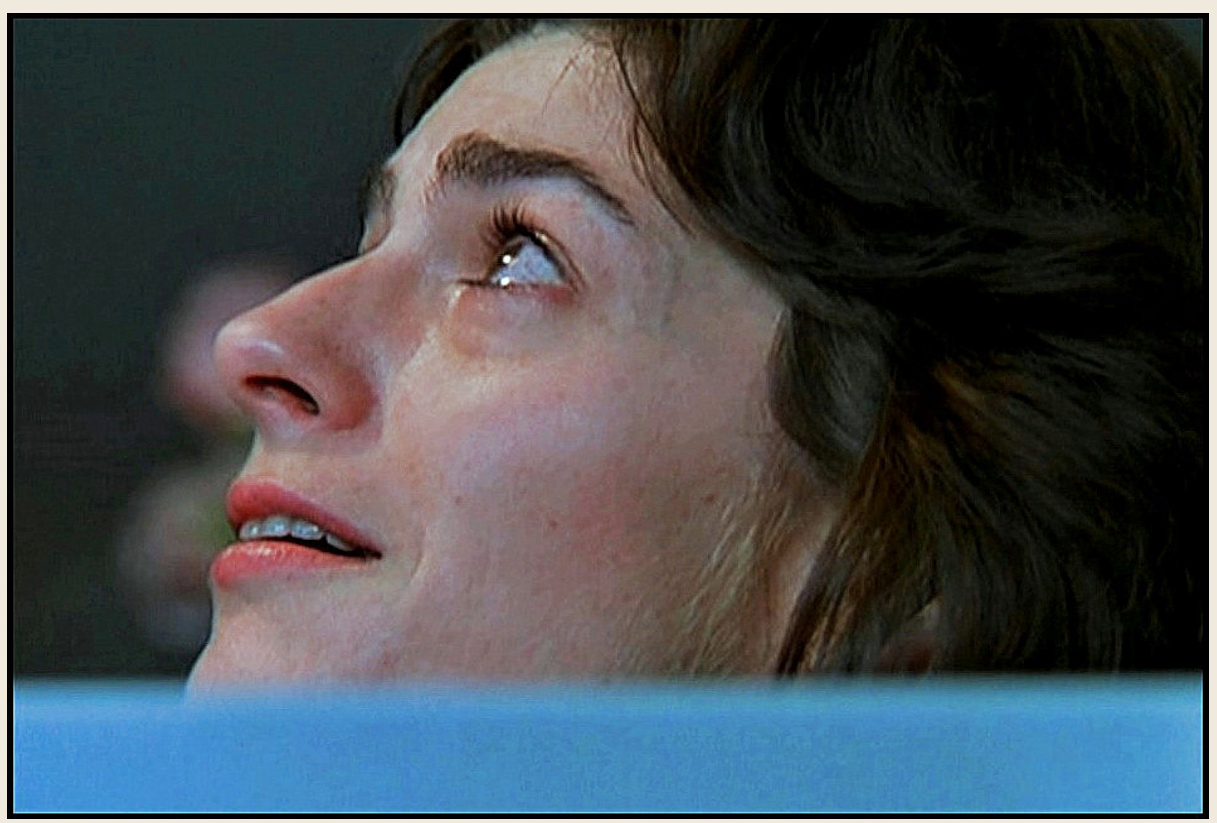

Foto 2 - Retalho da França.

Fonte: Imagem capturada do filme 11'09"01' (2002). 
No fim do curta-metragem (09'35"), posso enxergar um rosto feminino de perfil, voltado um pouco para cima, com os olhos dirigidos para fora do enquadramento. Há uma barra azulada na parte inferior. Também consigo olhar como a câmera selecionou focar o plano intermediário: o rosto - entre a barra anterior azul (filtro) meio borrada e o fundo bem mais esmaecido.

Na expressão facial da mulher (principalmente por conta de seus lábios e do fulgor nos seus olhos) ainda imagino ver um esboço de maravilhamento. Ou mais, uma nova emoção advinda de uma doce epifania. O que a mulher está mirando é uma lâmpada a piscar, anunciando uma coincidência salvífica para sua paixão, pois ela (antes com o cenho fechado e pesaroso) acabara de escrever notas finais de seu blues no laptop com tampa azulada: "vou deixar você [Jérôme] antes de você me deixar. A não ser que um milagre [...]" (11 de setembro, 2002, 09'30").

E o prodígio do acaso que poupou Jérôme reencantou uma apocalíptica saída para outro começo. Pnêumica na revelação de um êxodo pela chance de um novo gênesis.

\section{Retalhodo Egito}

Youssef Chahine (1926-2008) é o cineasta mais velho dentre os participantes do 11'09"01. Sem meias palavras, o veterano diretor carrega nos tons em sua denúncia contando uma estória surreal. Faz-se projetar no protagonista - um diretor que estava filmando a fachada do World Trade Center momentos antes dos atentados naquele 11 de setembro. No dia seguinte, já em Beirute para uma coletiva com a mídia, considera a entrevista inconveniente em face do ocorrido em Nova lorque.

Depois, procurando espairecer, o personagem fica à beira-mar admirando as ondas. Naquele instante, tem uma visão: um fuzileiro norte-americano emerge do Mediterrâneo para conversar. Aquele soldado é Danny, morto em uma ação terrorista dos palestinos em 1983.

Os diálogos entre Youssef e Danny são duros e cheios de informações sobre a participação direta e indireta dos governos estadunidenses em guerras e atentados mundo afora. $\mathrm{O}$ assunto, assim, comporta um debate mais agudo: a responsabilidade dos eleitores na fiscalização de seus dirigentes. Se o mandato emana da maioria de um povo, as ações dos seus dirigentes implicam numa corresponsabilização desses mesmos votantes. A população civil que deixa de se opor não está isenta de culpa quando os eleitos cometem crimes, especialmente fora de seu território. Os povos que sofrem essas agressões teriam, portanto, à guisa do talião, justificativa para contra-atacar (no caso, os civis norte-americanos), ainda que de modo terrorista (Foto 3).

No momento $06^{\prime} 45^{\prime \prime}$, posso enxergar um prédio ao fundo, uma mulher à porta com o braço erguido, outra pessoa dentro do prédio esburacado e algo muito escuro tomando metade do enquadramento à esquerda. Também consigo olhar como um veículo em movimento é captado pela câmera com baixa velocidade do obturador.

Ainda me é dilacerante à imaginação ver a mãe do homem-bomba que sai correndo de casa. Mostra para seu filho algo que havia preparado. Observada pelo marido, ela se agita e se angustia por não conseguir entregar o lanche. O filho acabara de se vestir com dezenas de explosivos. Dera partida no veículo também abarrotado de bombas. Estava deixando a família para sempre. Era um palestino suicida a cumprir sua missão sagrada: explodir o prédio do quartel dos fuzileiros navais norte-americanos em Beirute, matando quase trezentos.

A mãe, ofertando aquela merenda preparada com suprema e terna paixão, encarnava a fé - essa experiência caracterizada pelas adversativas mais radicais. Diante do inaceitável, uma renitência visceral. 


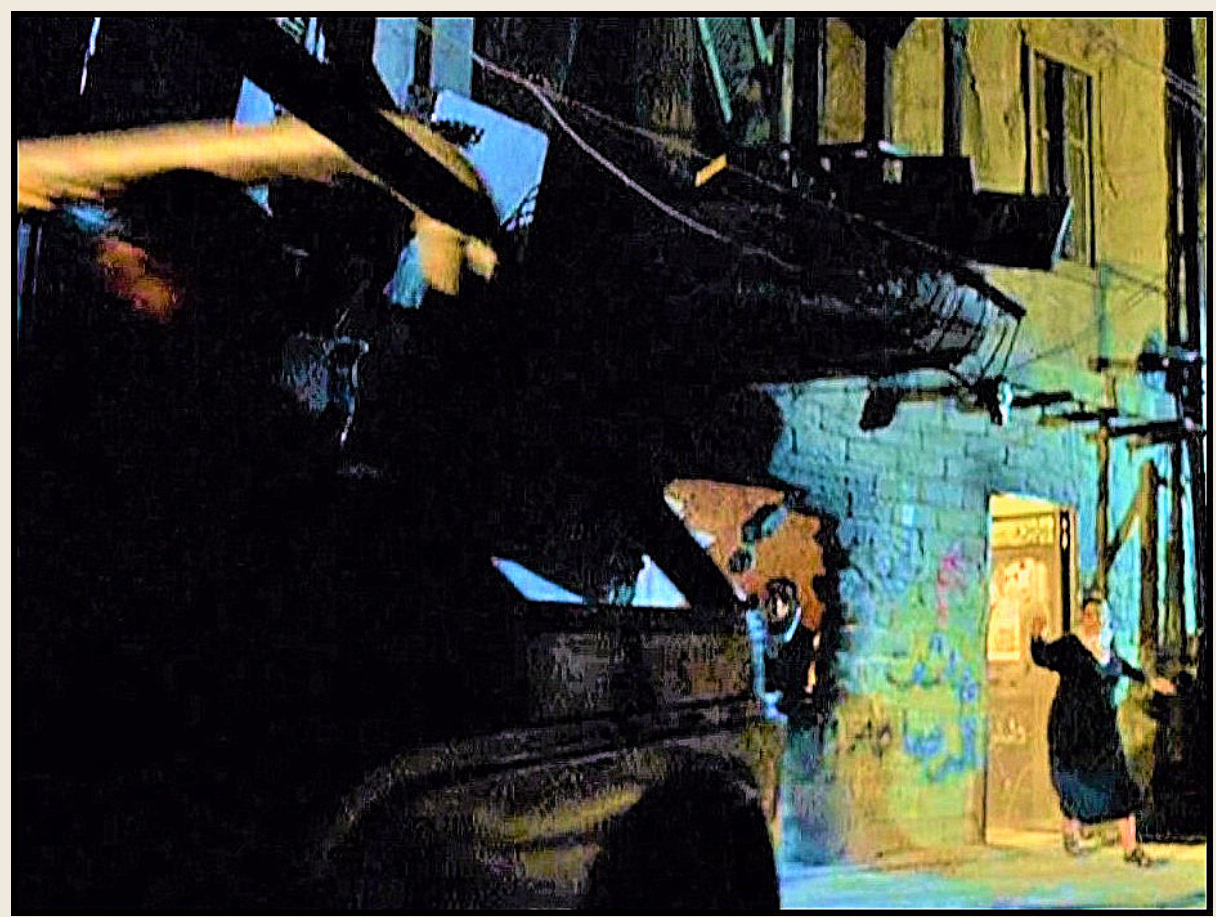

Foto 3 - Retalho do Egito.

Fonte: Imagem capturada do filme 11'09"01' (2002).

Ainda que, apesar de... Subsiste um contudo, um todavia, um porém. Exercício de uma santa loucura inescapável, inexpugnável e intransferível.

Por que um lanche para um motorista em viagem sem desembarque?

Não haveria tempo...

Por que uma desmesurada expectativa contra tanto indício?

Não houve lógica...

Por que uma reta certeza sem recuo e sem recusa?

Não há como...

Pnêumica da teimosia como surpresa inventiva.

\section{Retalhoda Bósnia-Herzegovina}

Danis Tanovic nascido em 1969, consegue elaborar um encontro pesaroso e solidário numa trama densa e com sóbria potência. Reúne as dores das perdas entre pessoas tão afastadas e mais diversas ainda. Põe em paralelo as pertinentes manifestações de luto e de protestos na América e nos Balcãs do sudeste europeu. É uma película antagônica ao esquecimento.

O diretor, também roteirista, opera com grande maestria, delicadeza e primor fotográfico. Sonoriza e rege com ruídos corretos (só duas vezes há música em rápidos segundos). Soberbo nos enquadramentos, detalhes e closes, conta a estória de Selma naquele 11 de setembro de 2001.

Depois de uma noite sem dormir, Selma se prepara para a manifestação em memória das vítimas do Massacre de Srebrenica - genocídio sofrido pelos bósnios, principalmente os mulçumanos, em 11 de 
julho de 1995. Com sua vida empacotada desde essa data, Selma pena há longos seis anos purgando parcas esperanças e profundas saudades.

Para ela, a terrível notícia ouvida pelas ondas do rádio na sede da associação das mulheres (informando sobre a queda das Torres Gêmeas) não deveria suspender - como pensavam sustar as outras mulheres do grupo -, a série até então ininterrupta de manifestações todo dia 11. Às 16h Selma decide que fará a manifestação na praça, mesmo desacompanhada. Uma andorinha só não faz? Verão:

Sozinha à porta da agremiação feminina (provavelmente em sua maioria composta de viúvas), Selma é encorajada pelo amigo Nedim, que puxa a corda na qual foram inseridos os cartazes de panos com os nomes das vítimas. Chegando à praça, Selma é irmanada pelas colegas regeneradas que, lenta e silenciosamente, se ligam pelo encordoamento (Foto 4).

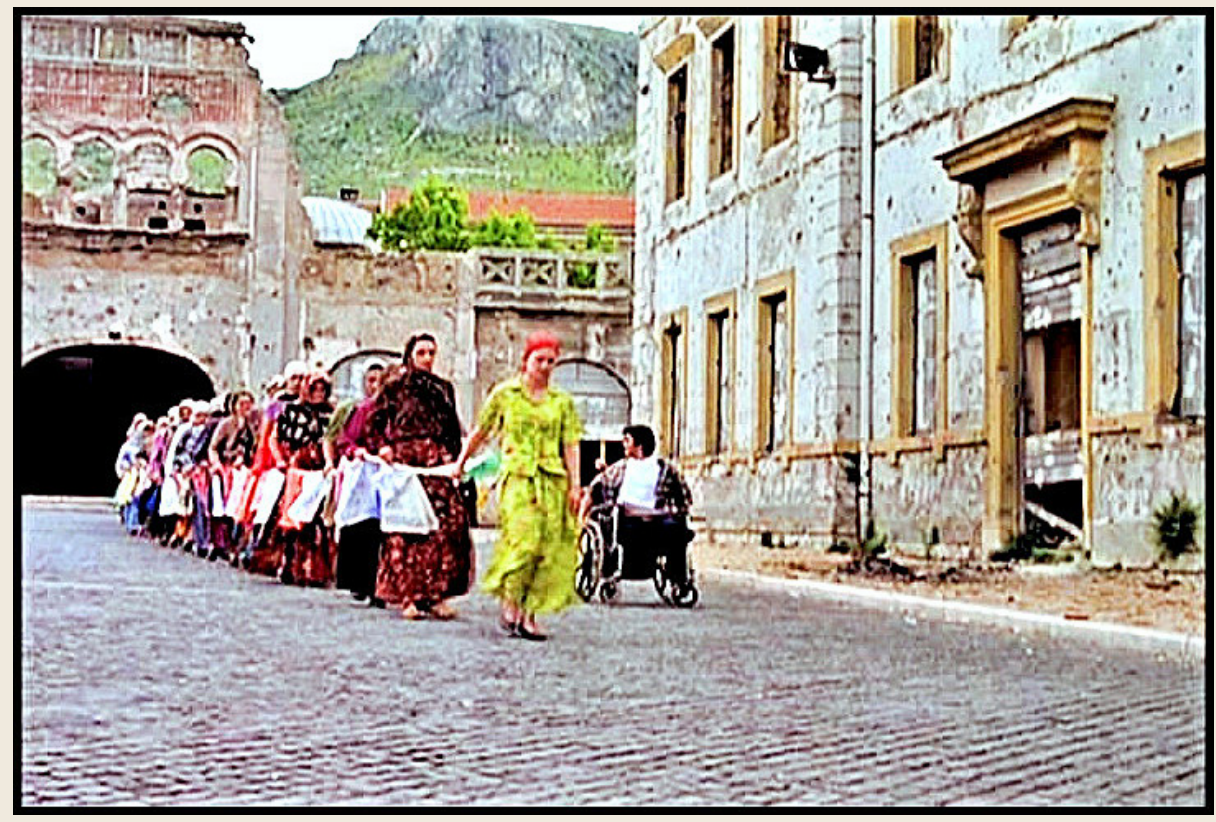

Foto 4 - Retalho da Bósnia-Herzegovina.

Fonte: Imagem capturada do filme 11'09"01' (2002)

Ao final do curta-metragem ( $\left.09^{\prime} 55^{\prime \prime}\right)$ posso enxergar um homem numa cadeira de rodas e mulheres com vestimentas coloridas. Paredes e prédios marcados. Também consigo olhar como a câmera registra a cena à altura equivalente aos olhos de alguém numa cadeira (de rodas?). No enquadramento é engendrada uma transversal desde um largo ponto escuro ao fundo.

Na imagem ainda me deslisa um apelo pnêumico para ver Selma personificando uma práxis de superação-e-fidelidade. Seu melhor sentido de existência ficou amputado-para-sempre, assim como se mostrava perene sua escolha pela mansidão corajosa. Desde aquela madrugada, um ritual de confirmação se estendeu. Além das incomparáveis perdas de seus parentes no massacre de 1995, ela perdeu o sono, perdeu o cartaz antes preparado, perdeu o apetite para comer, perdeu das companheiras o habitual espírito combativo coletivo. Porém não perdeu seu jeito humanista e destemido.

Com pontas no início, na metade e no final do segmento Nedim - um simpático cadeirante/ sobrevivente, sem ambas as pernas e com muito bom-humor -, é emblema da graça. Um coadjuvante 
precioso, cujo posicionamento nesse epílogo (ao lado de Selma) como que centraliza um retângulo resiliente - aliás, com a diagonal da denúncia tangenciando cores a partir de um pórtico vazio trevoso.

Pnêumica que emoldura uma antinomia indispensável: a paz de consciência na luta conscientizadora.

\section{Retalhoda Burkina Fasso}

Idrissa Ouedraogo (1954-2018), mestre do melhor cinema africano ocidental, teve a competência de articular complexidades em seu segmento. Usou tanto a língua francesa quanto a autóctone. Mostrou simultaneamente raízes do riso e da tristeza. Trouxe o hilário nonsense e a pura amizade. Principiou e concluiu em nome da dor e das limitações materiais. Sem concessões, exceto às ironias, recheou tudo com rústicas pitadas das tradições mais primevas - sem as quais não se poderia chegar aos sofisticados aparatos tecnológicos do século 21.

O curta-metragem conta a estória de Adamà - um adolescente que tem a mãe enferma e sem condições de tratamento adequado. A cena com a mão sobre o rosto da mãe é comovente: Pietà trocando os papéis.

O garoto precisa deixar a escola para conseguir dinheiro como vendedor de jornais nas ruas. Com isso, toma conhecimento de que o governo estadunidense, dez dias depois da tragédia em Nova lorque, está pagando 25 milhões de dólares pela captura de Osama bin Laden.

Por mera fatalidade, Adamà visualiza um homem com a aparência de Osama e, para obter o prêmio, combina com os colegas caçarem o sósia-involuntário. Não conseguem.

Enfim, supondo que Bush poderia visitar a cidade onde moram, começam a aventar um sequestro do presidente americano para faturarem com o resgate que exigiriam. Ou, numa alternativa mais exequível e caseira: decidem vender a filmadora sem uso que tomaram "emprestado" do pai de um deles e, com isso, comprar remédios para a mãe de Adamà (Foto 5).

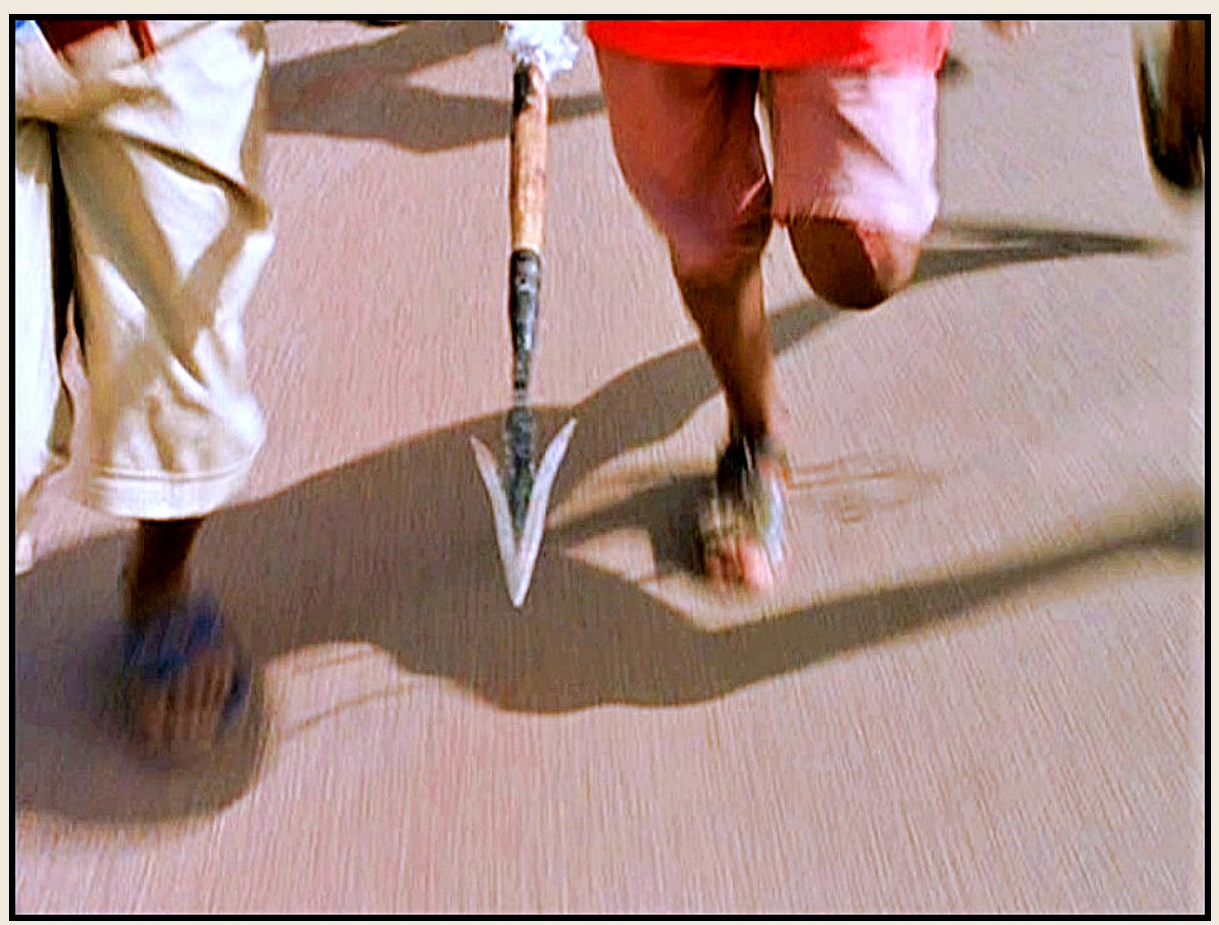

Foto 5 - Retalho da Burkina Fasso.

Fonte: Imagem capturada do filme $11^{\prime} 09^{\prime \prime} 01^{\prime}$ (2002). 
Por volta de $08^{\prime} 40^{\prime \prime}$, posso enxergar, ao centro, a ponta de metal duma lança de madeira. À esquerda, uma calça clara e um pé; à direita duas coxas, uma perna e um pé. Também consigo olhar como a câmera registra quatro pessoas correndo (duas no quadro e duas fora). Pelas cores ou pelas sombras sei que todas elas correm tendo o Sol à esquerda.

E ainda confesso ver o que Sigmund Freud talvez explicasse: na posição explícita da ponta da lança sobre a sombra da cintura do jovem extraquadro há uma implícita sugestão de um pênis prateado e desperto - possível ícone e índice do símbolo de potência. Deslocamento interpretativo. Metonímia malandra.

Quem sabe essa invenção de sentido coubesse para traduzir pulsões de vida e de morte tratadas no segmento: a grande competência necrófila dos autores e atores dos atentados em Nova Iorque; a agonia terminal da mãe de Adamà; um jato de paixão contra as torres; uma flecha ancestral a serviço da saúde; uma corrida ao encalço da ilusão; uma projeção la(n)çada pelo desejo; uma energia libidinosa; um arranque castrador. Pulsões de Eros e Thanatus encarnadas nas loucuras e lindezas da história.

Qualquer hipótese de sanidade física ou mental, particular ou coletiva, oscila entre a insegurança do intempestivo e o cálculo oportunista: o tesão emergindo das obscuridades e apontando para torres de ontem e terras de sempre.

Pnêumica dos humores inapreensíveis e engenhosos. Pnêumica em transe.

\section{Retalhodo Reino Unido}

Ken Loach nascido no ano de 1936, é um dos mais respeitados diretores no velho mundo, compromissado com as causas trabalhistas e socialistas. Participou do 11 '09"01 fazendo do evento de 2001 em Nova lorque uma oportunidade para retomar a memória de outra história: o golpe militar patrocinado pelos Estados Unidos contra o governo socialista de Salvador Allende, eleito de modo democrático no Chile em 1970. Usando material de reportagens autênticas, Loach (ganhador do prêmio na categoria curta-metragem no Festival de Veneza de 2002) reconstrói a história do protagonista Pablo - codinome de Vladimir Vega, homenageando Neruda.

Vega foi ator, cantor, compositor, instrumentista tanto no segmento de Loach quanto (muito mais) na vida real. Faleceu em 2013, aos 60 anos.

Preso em 11/9/1973, torturado pelas forças de repressão do abominável Pinochet e cinco anos depois exilado em Londres, Pablo/Vladimir escreve uma carta de solidariedade aos norte-americanos poucos dias antes do primeiro aniversário da queda das Torres Gêmeas. Destaca que ambos os 11 de setembro (1973 e 2001) foram terças-feiras. Nesses dias, muitas vidas de chilenos e de norte-americanos foram destruídas para sempre. Também por essa infeliz convergência na representação cronológica e na dimensão existencial, Pablo entende e conclama que os sentimentos deveriam promover empatias mais profundas.

Pablo não tem como voltar para sua terra sem gerar prejuízos irreparáveis a seus filhos nascidos, criados e estabilizados em Londres. Seria colocá-los em situação de desterro que ele mesmo sabia o quanto custava. Para apaciguar a sus nostalgias, Pablo se vale da arte (Foto 6). 


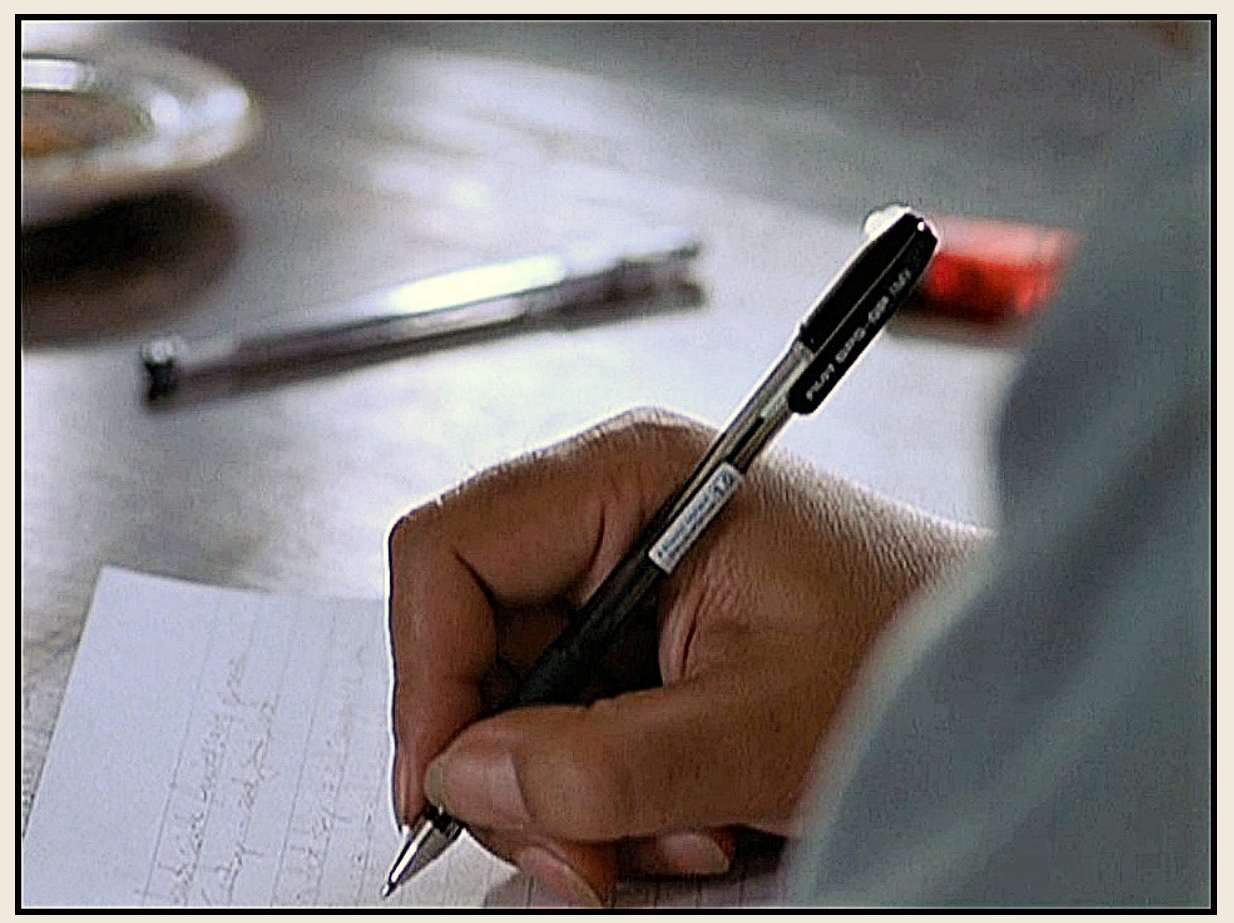

Foto 6 - Retalho do Reino Unido.

Fonte: Imagem capturada do filme 11'09"01' (2002).

No final do curta-metragem (10'35"), posso enxergar uma caneta na mão direita, uma folha de papel com algo escrito. Desfocados aparecem três outros objetos: um isqueiro, uma caneta e parte de um pires-cinzeiro. Também consigo olhar como a lente, próxima, tinha milímetros suficientes para focar apenas a mão. Assim como as unhas compridas na mão direita indicam um violonista destro.

Uma faixa desfocada no alto da foto ainda me convoca a ver sinais transcendentes:

Pablo escreveu em inglês Tuesday - dia de Twi (brilho). Porém Pablo é chileno e sentiu Martes - alusão ao deus romano Marte (deus da guerra), Ares na mitologia grega. Literalmente, terça-feira é fogo! Haja isqueiro para aplacar a ira das divindades!

Uma caneta descansa ao se recompor de lutas e labaredas. Foi mídia a psychographar, numa pauta patrística, uma frase irretocável de Agostinho: "A esperança tem duas filhas lindas: a indignação e a coragem. A indignação nos ensina a não aceitar as coisas como estão; a coragem, a mudá-las" (11 de setembro, 2002, 10'05").

Um pires-cinzeiro pela metade talvez contenha apenas meias-verdades. Não é possível comportar nem contabilizar cinzas humanas (3.000 sob as Torres; 30.000 sob a ditadura). Mas, além de vingança ou azedume, o que conta: vidas não são números; vidas infinitam...

Pnêumica do alívio lúcido. Pnêumica do fôlego intrépido.

\section{Retalhodo México}

Alejandro González Iñárritu nascido em 1963, surge como um dos mais badalados dentre os 11 diretores. Nome premiado e consagrado principalmente pela crítica especializada (Amores perros, 21 
gramas, Babel, Biutiful, Birdman, The Revenant...). Com um toque experimental, sua intervenção neste 11'09"01 tem a pungência polêmica própria dos traumas embaraçados e recorrentes.

A tela permanece escura quase o tempo todo. Lampejos ferem a recepção espocando frações muitíssimo ínfimas de minutos com cenas de corpos caindo das Torres Gêmeas.

Sons identificáveis (ou não), sons de conversas, noticiários, pancadas, sirenes, gritos, gemidos, pavor, música lenta e melancólica, cantos e orações de Chiapas, etc. conduzem incessantemente os sentidos e sentimentos a partir de sensações sem linearidades.

A música que entra aos 07'50" e segue até 10'40" é o belíssimo Adagio for strings (1936), de Samuel Barber (1910-1981). Nesse trecho a tela vai recebendo suavemente mais luz. Tem-se a impressão de que as dores estão recebendo seu lenitivo. E já com plena claridade surge uma frase contendo um incontornável enigma. Uma pergunta desconcertante: A luz de Deus nos guia ou nos cega? Daí a tela recebe tanta luz que obnubila. E a catarse (além de purgar) elucida. O assombro incognoscível é deslindado; cai a ficha.

De sobressalto em sobressanto, Iñárritu concede ao telespectador uma estranheza estética; uma experiência nova a despeito do que a imprensa saturou à época (Foto 7).

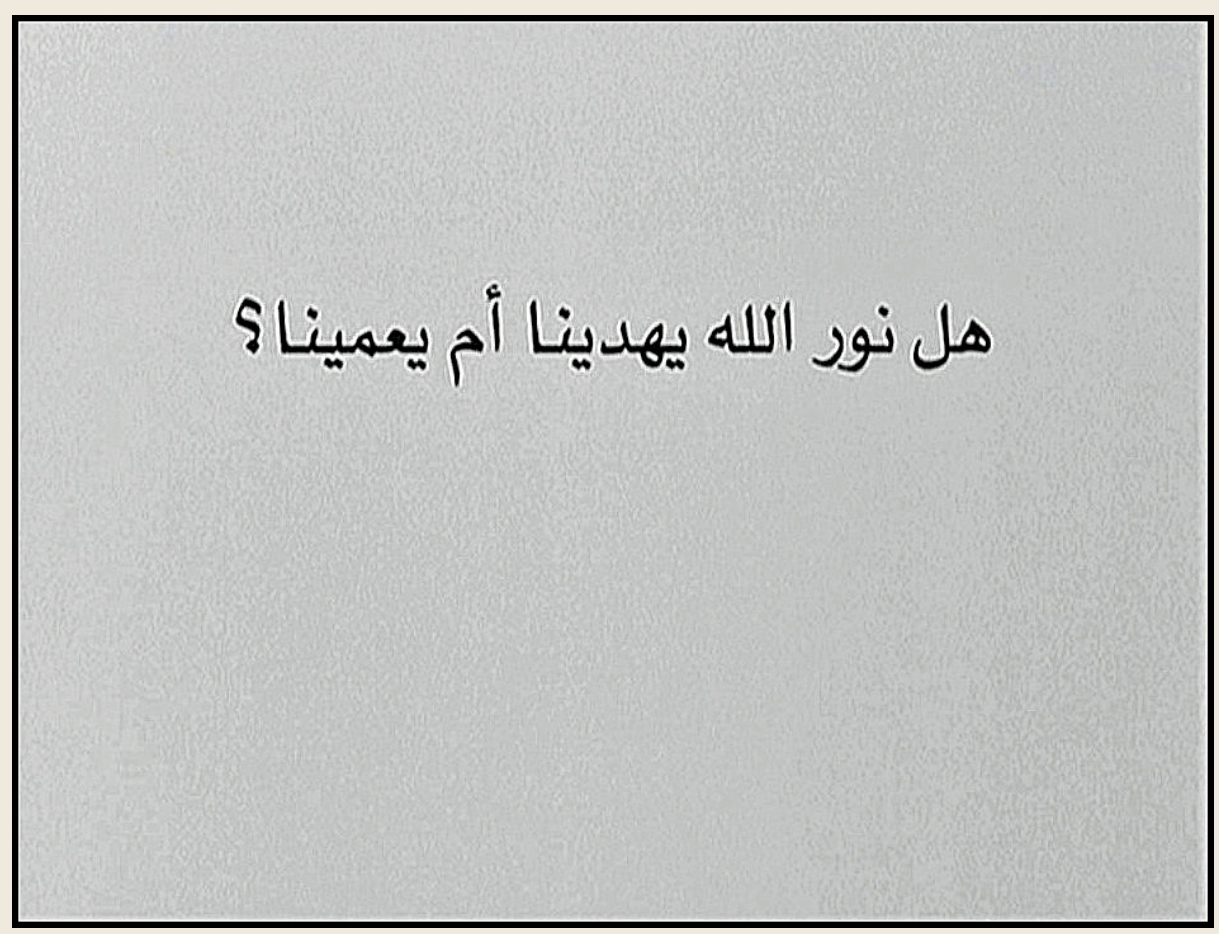

Foto 7 - Retalho do México.

Fonte: Imagem capturada do filme 11'09"01' (2002).

A imagem acima surge lentamente em fade in aos 09'30". Aos 09'50" há um acréscimo de palavras inglesas em paralelo. Aos 10'22" ambas as linhas são atravessadas e estouradas por uma rajada de luz muito intensa. Posso enxergar uma linha horizontal na parte superior, com traços e pontos. Também consigo olhar essa linha com a suspeita de que se trata de uma escrita árabe. 
E porque "os limites de minha linguagem denotam os limites de meu mundo" (Wittgenstein, 1968, p. 111) ainda me é forçoso ver que por efeito de ignorância em relação ao idioma árabe acabo me valendo da tradução que aparece em paralelo segundos depois (e já citada acima): "Does God's light guide us or blind us?" Admito, portanto, que me falta tanto...

Na falta de luz ou ausência de script creio que subjaz a dimensão trágica do referente. Com pouca luz ou luz excessiva para enxergar e olhar, como ficaria uma iluminação para ver?

Sinto ao ver na edição desse segmento uma discreta semântica de insinuações. Descola-se um tema: o suicídio. Mesmo dentro de um tabu na comunicação social, o segmento convida a uma difícil meditação sobre o suicídio do terrorista contra as Torres e sobre o aterrorizado suicida contra o chão. A ideologia sustentando o primeiro e o escape saltando no segundo. Aquele em obediência cega ao determinado e esse na viabilidade indeterminada de uma escolha. De um ângulo, a cultura da formatação; de outro, a subjetividade amorfa no momento.

Pnêumica de gênios e desgostos em garatujas; bruxarias e bruxismos no breu.

\section{Retalho de Israel}

Amos Gitaï nasceu em Haifa no ano de 1950. Tem formação em arquitetura e doutorado em Berkeley em 1979. Além de cineasta, escreveu peças para o teatro. Como catedrático, lecionou na University of California em 2017, no Collège de France em 2018 e na Columbia University em 2019.

Seu segmento no 11'09"01 foi rodado de uma vez (um único plano sequência) - o que demandou, por certo, uma preparação meticulosa e uma direção cirúrgica. E, nesse feito, a tomada de cena aconteceu numa velocidade alucinada, frenética, implementando um ritmo caótico, apenas aplacado ao seu término.

O tema de Gitaï apresenta um ambiente de socorro às vítimas de um grave atentado numa rua de Tel-Aviv. Dois carros-bombas explodem e não se sabe se outras detonações podem suceder. No espaço de poucos metros, próximo a uma esquina da Rua Jerusalém, se amontoam polícia técnica, agentes de trânsito, ambulâncias, enfermeiros, fotógrafos, cinegrafistas, etc. Tudo em meio a muitos curiosos e ao importante comércio local às vésperas do Rosh Hashaná (Ano novo judaico de 5762).

Pela metade do segmento, chega outra equipe de televisão para a cobertura jornalística. A câmera que registra o curta-metragem, com um golpe de licença narrativo-visual, assume eventualmente a função de captura de vídeo pela equipe recém-chegada.

A repórter tenta colher e passar informações ao vivo para os telespectadores. Durante seu dedicado e incansável empenho, vem a saber que sua matéria está sendo preterida por causa de outra ocorrência em Nova lorque. Não se conforma e discute com a direção do programa. Chega a elencar diversos fatos históricos importantes acontecidos em 11 de setembro. Sua argumentação é confrontada pela magnitude da catástrofe com as Torres Gêmeas. Vencida, ela se afasta vagarosamente e senta no meio-fio, longe da confusão (Foto 8).

Nos últimos segundos desse curta-metragem (10:40) posso enxergar, nítido à esquerda, um elemento com ranhuras. Ao centro e à direita, embaçados, trecho de rua com algumas pessoas, prédios, uma banca e vários veículos. Também consigo olhar como a lente da câmera focou só o primeiro plano. Fez um enquadramento a mostrar um grosso tronco de árvore à esquerda e algumas folhas verdes numa nesga superior. 


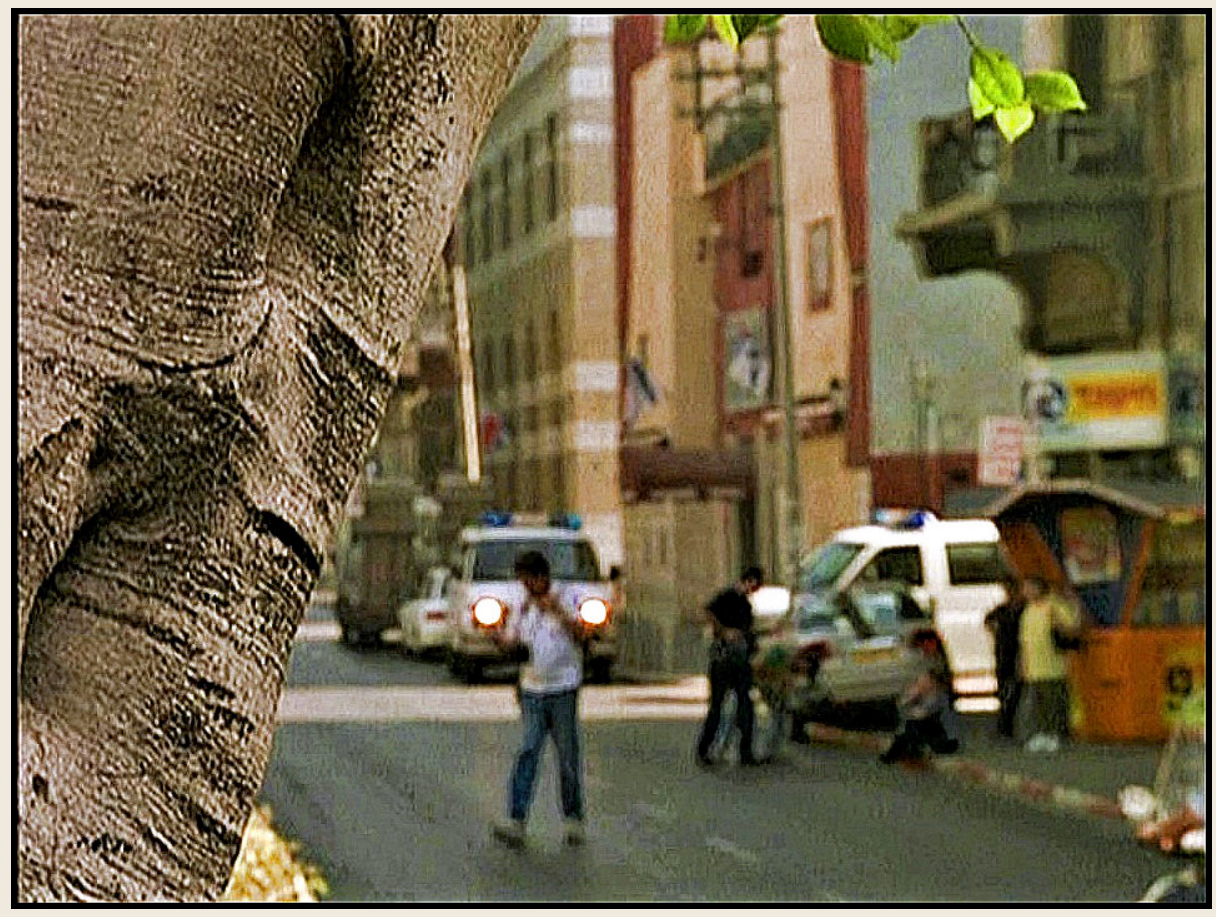

Foto 8 - Retalho de Israel.

Fonte: Imagem capturada do filme 11'09"01' (2002).

Nessa imagem ainda repousa um convite para eu ver uma pausa contemplativa diante de um cansaço na existência que extenua, que deixa delgado, franzino e débil o fio do viver... É como um aceno à trégua meditativa diante de um cansaço que também exaure, que esgota completamente as forças da sobrevivência... Vejo um chamado à folga reflexiva diante de um cansaço que ainda extingue, que destrói, aniquila e apaga por inteiro uma, duas, centenas, milhares de vidas. Em tempo, relato que escrevo este artigo no outono de 2021, em meio à pandemia e seus pandemônios. Quanto cansaço, quanto viver debilitado, quanta sobrevivência esgotada, quanta vida destruída!

Pnêumica da súplica por verdejâncias: campinas e parques pastorais.

\section{Retalho da Índia}

Mira Nair nasceu em 1957. É socióloga formada na Miranda House (University of Delhi) e depois na Harvard University. Sua carreira como cineasta é notável. Entre outros, ganhou o prêmio Leão de Ouro de melhor filme (Matrimônio indiano) no Festival de Veneza de 2001.

Deve ter ouvido na Miranda House que seu fundador, Sir Maurice Lindford Gwyer, afirmava que Carmen Miranda era sua atriz favorita e que ele havia nomeado sua filha Miranda por causa dela e, ainda, que exemplo de mulher deveria ser a personagem Miranda da peça A tempestade, de Shakespeare. Essa trindade de Mirandas talvez tenha influenciado Nair.

Esse curta-metragem no $11^{\prime} 09^{\prime \prime} 01$ certifica a coerência de sua postura feminista. O enredo é baseado em uma história real: a morte de Mohammad Salman Hamdani em 11 de setembro de 2001. Paquistanês, nascido numa família de fé mulçumana, chegou bebê aos Estados Unidos. Quando jovem, participou ativamente da cultura norte-americana, fazia parte do time de futebol da Bayside High School, 
foi cadete do Departamento de Polícia de Nova lorque, formou-se em bioquímica, era paramédico, queria cursar medicina e trabalhava como pesquisador no Protein/DNA Technology Center.

É tomado como desaparecido naquela terça-feira, aos 23 anos. No transcorrer da semana surgiu a suspeita por parte das autoridades de que Salman também poderia ser um terrorista. Sua mãe Talat - protagonista no segmento - liderou a família na versão oposta: seu filho era um bom rapaz americano.

Respondendo a investigadores em seu lar, a mãe mencionava as atividades e as preferências de Salman. Chegou a cometer um equívoco ao trocar o nome de um filme, cujo cartaz enfeitava a parede da casa. Ao invés de dizer Star War falou Star Trek - essa alteração soa extraordinária para aquilo que Talat preferia: uma jornada, não a guerra.

Em outubro foi encontrado o corpo de Salman nos escombros da torre norte do World Trade Center e constatou-se que o paquistanês muçulmano morrera enquanto atendia, como técnico de emergência médica, as vítimas do desastre. Foi sepultado em 05/04/2002 como herói após veemente discurso de Talat (Foto 9).

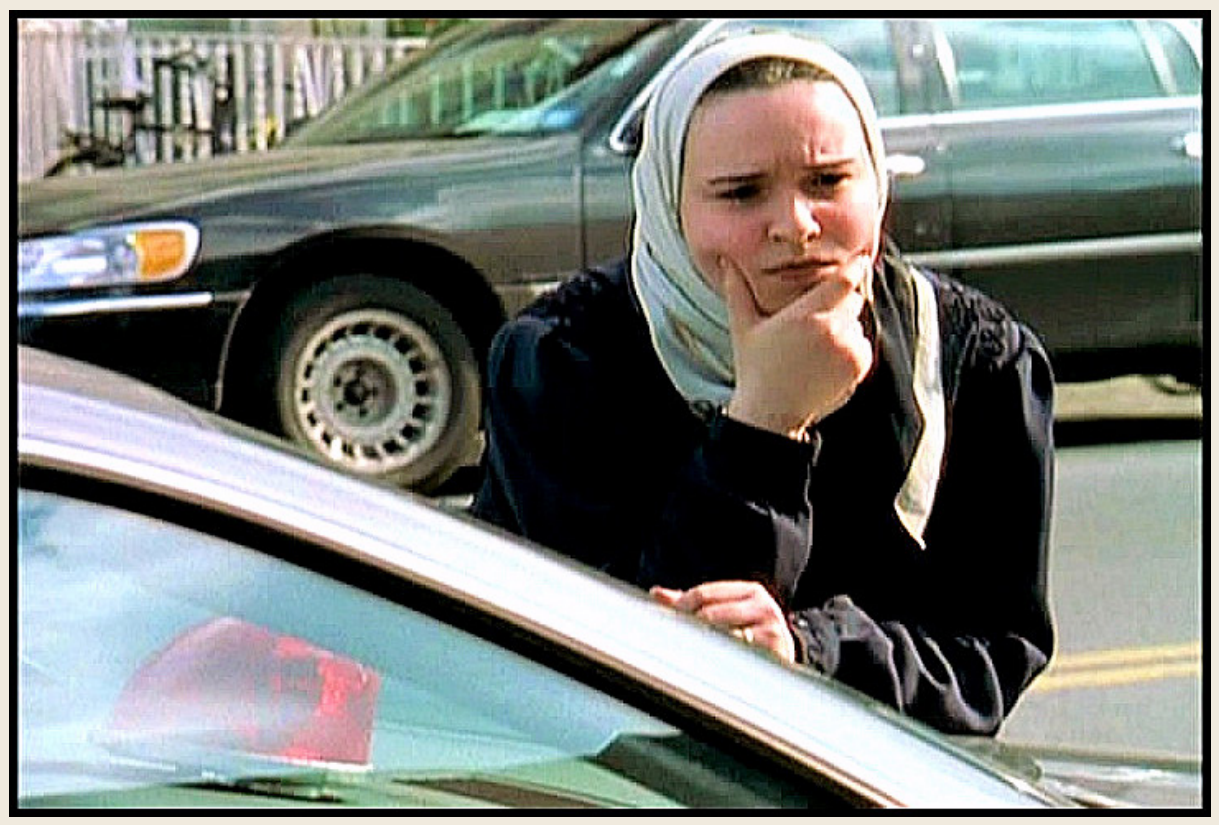

Foto 9 - Retalho da Índia

Fonte: Imagem capturada do filme 11'09"01' (2002).

Aos 03', com a breve duração de quase 02 segundos, posso enxergar uma jovem com lenço na cabeça apoiando seu rosto sobre a mão direita. Seu outro braço descansa em cima da lataria de um carro. Ao fundo, outro veículo. Também consigo olhar como um anel na mão esquerda possa ser indicativo de compromisso. E que o luminoso vermelho (que piscou no filme) sugere que o veículo faça parte da frota de policiais.

Ainda me subsiste uma brecha para ver uma súbita amostragem de desvio. O que sai do encaminhamento mais reto e curto às vezes se equipara ao erro; noutras, à tática correta. A fala prolixa peca; o dizer parabólico atinge o objetivo dando uma volta. Excursionar tanto pode levar à labiríntica inconsequência quanto à recreadora conquista. 
As autoridades falharam e se perderam no atalho da xenofobia e da islamofobia. A mãe de Salman acertou na distração verbal. O único aparecimento dessa moça (no vão entre os carros) em menos de dois segundos seria um lapso icônico? Para uma diretora como Nair, até uma lépida fração de cena pode evocar uma profundidade de apreensão reprimida.

Pnêumica do hermético tropeço íntegro. Pnêumica na trincheira da estrela errática.

\section{Retalhodos Estados Unidos}

Sean Penn nascido em 1960, detém um respeitável currículo como ator premiado. Atrás das câmeras sua carreira na direção é tardia, e esse segmento no 11'09"01 suscitou muita controvérsia. Estou entre aqueles que elogiam essa delicada crônica sobre a queda das Torres Gêmeas. De cara, sublinho o requinte dos enquadramentos, a paleta do cenário e dos objetos cênicos, a condução do ator e a corretíssima trilha sonora composta pelo brasileiro Heitor Pereira.

A estória é a seguinte: um viúvo aposentado (magistralmente vivido por Ernest Borgnine) contracena com seu delírio. Esse desvario é personagem ao nível de seu desejo: sua esposa ainda viva. Quando o despertador toca às 8h, esse senhor já está em pé com a barba feita; é hora de escolher o vestido para a esposa - ainda na cama. Antes, porém, dá um xêro gostoso na camisola; decide pela roupa que combina com a estação. Depois, faz as refeições conversando com ela, num kitnet antigo a oeste de Manhattan. No bate-papo se queixa da falta de luz no apartamento - razão das flores junto à janela estarem secas.

No filme, muitas experiências sensoriais (escutar, tocar, cheirar, enxergar e degustar) são representadas em closes, às vezes em slow motion. Noutras sequências há sobreposições de imagens e divisões da tela em duas ou mais fatias verticais ou horizontais. A edição chega a ecoar a confusão instalada no interior daquele viúvo, sendo a fotografia uma hábil substituta do discurso verbal e a trilha sonora um sutil comentário sem palavras.

Toda noite ele deixa a televisão funcionando sem som e se liga no sono. Na manhã de 11 de setembro, o despertador (que aparentara defeito) não toca. Passa das 9h16. Ele perdeu a hora; está dormindo. Entra uma luz de verão no apartamento - antes dominado pela sombra da torre sul do World Trade Center. Ele acorda e nota que as flores (metáfora da esposa) renascem com todo seu luxuriante colorido. Encantado, levanta e leva o vaso ao lado da cama onde dorme a esposa. Diz palavras transbordantes de carinho, afeto, ardor... Ela não reage, não responde. Ela não existe mais, senão na fantasia dele. Só nesse instante ele assimila que perdera a esposa. Chora. Chora abatido, destruído, acabado. E termina pranteando o infortúnio dela não sentir o ansiado milagre da ascensão das flores: "Ah! Você precisava ter visto, amor! Você precisava ter visto! Eu queria que você visse!" (11 de setembro, 2002, 10'50") (Foto 10).

Pouco antes (08'45"), posso enxergar manchas coloridas e a metade do rosto de um homem idoso. Também consigo olhar como a câmera usa uma lente ajustada para desfocar o primeiro plano. E mais: no minuto seguinte aparece a trucagem reversa concomitante à vinda do senhor à frente para conferir a mágica ressurreição das flores.

Ainda acredito ver um cenáculo prestes à síncope, um abrigo à beira do colapso. 


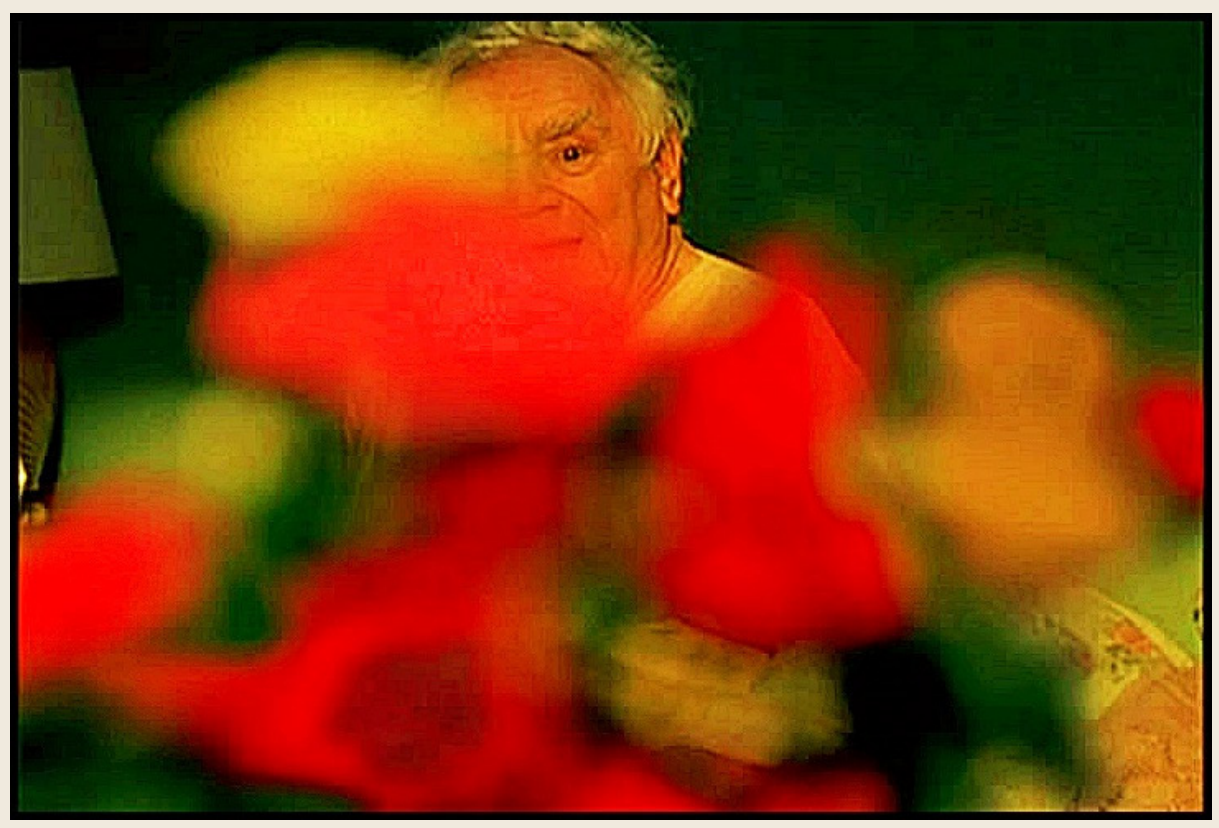

Foto 10 - Retalho dos Estados Unidos.

Fonte: Imagem capturada do filme 11'09"01' (2002).

Sem negar o absurdo das hecatombes, como abafar incêndios no recôndito da alma solitária? Maybe fake flowers aliviem o fiat lux suspirado. Afinal, "o que seria de nós sem o socorro daquilo que não existe?" (Valery, 1930, p. 256, tradução minha)³.

E para comungar na ilusão poética do segmento, devaneio que o viúvo reencarna ou transubstancia o Carlito de Tempos Modernos: sua inconsciência nos conscientiza!

Pnêumica da terapia por contratempo. Pnêumica do capcioso paradoxo do truco.

\section{Retalho do Ja pão}

Shohei Imamura (1926-2006) iniciou sua carreira no cinema como assistente depois de se formar em História na Universidade Waseda. Premiado duas vezes em Cannes, Imamura deixou um legado de qualidade e densidade raras. Sua vasta obra terminou com o curta-metragem que também encerra este 11'09"01. Coerente com a prática de aprontar surpresas, seu segmento é o único que não tem nada explícito em relação à destruição das Torres Gêmeas. Nem por isso sua participação fica descabida. Ao contrário, talvez Imamura tenha atingido o caráter central de toda aquela tragédia em Nova lorque. A cena final decreta uma frase perfeita: "nenhuma guerra é santa".

Imamura e seu filho roteirista Daisuke Tengan contam uma estória com a câmera sempre firme, muitas vezes rente ao chão, registrando iluminação e enquadramentos acurados. Os atores esbanjam experiência.

Yukichi Furuhashi é o protagonista - um soldado japonês que volta para casa de seus pais e esposa pouco antes de terminar a Segunda Guerra. Sofre severos traumas na chamada Guerra Santa contra os chineses, quando lutou por seu país e deu tudo pelo Imperador.

\footnotetext{
${ }^{3}$ No original: "Que serions-nous donc sans le secours de ce qui n'existe pas?" (Valery, 1930, p. 256).
} 
Ao se comportar como cobra (rasteja tremulando a língua para fora, ataca galinhas e carpas da vizinhança, come rato, etc.) Yukichi vive uma experiência "terrível", conforme a expressão de seu próprio pai Sakichi. Sua família tenta administrar o inusitado, contudo não obtém bons resultados.

Expulso de casa pela mãe Kayo depois de profanar a memória do avô, Yukichi atravessa a mata e chega à beira do riacho. Sob a beleza da lua sua reação é um bocejo de tédio e desencanto, afinados como assovio definitivo de poslúdio reptiliano.

Sua esposa Sae lá aparece por casualidade e Ihe pergunta: "ser homem enoja você tanto assim?" Decerto que não seria nesse instante que Yukichi recobraria a fala; então se lança na correnteza sorvendo uma extremada unção da esposa: "Querido! Querido!"

Constatando a perda definitiva de Yukichi, Sae talvez retorne para seu amante (Foto 11).

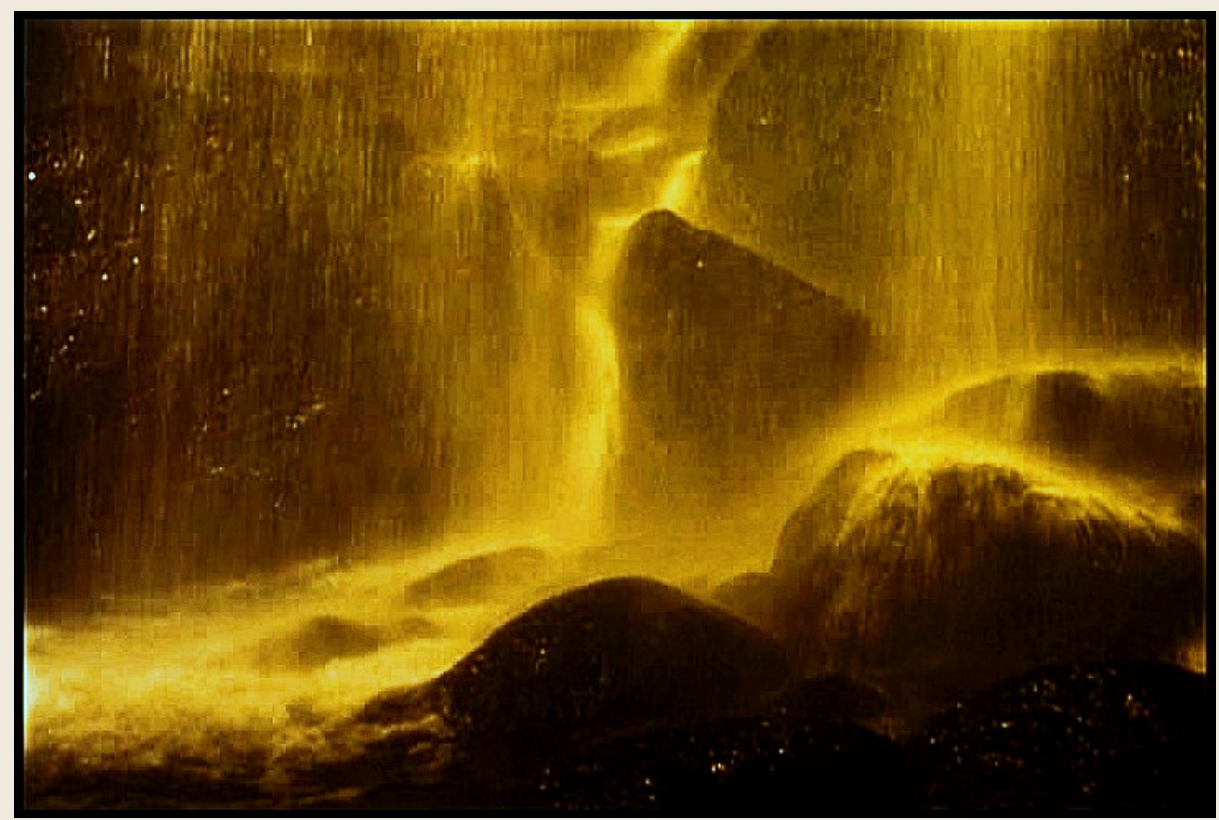

Foto 11 - Retalho do Japão.

Fonte: Imagem capturada do filme 11'09"01' (2002).

Quase no final $\left(09^{\prime} 25^{\prime \prime}\right)$ posso enxergar um quadro com tons de marrom. Algumas pedras na metade direita, parte de baixo. Muitas manchas claras espalhadas. Também consigo olhar como a câmera registrou, com obturador em baixa velocidade, uma cachoeira. O jeito leitoso da água combina com a lua que aparecerá na foto seguinte do segmento.

Daí ainda emerge uma pululante chispa para eu ver um retrato, sob o aspecto da eternidade, de uma súmula a respeito do belo e do sublime.

A plástica arrumada no quadro traduz uma luminosidade que extravasa, fluida e fluída. Fluida em contraste aos minerais e fluída por entre as pedras, essa luz sépia emana beleza. Apazigua e conforta.

Porém, essa mesma plasticidade assoma um obscuro complementar. Límpido em primeiro plano e mais diáfano e copioso debaixo das cortinas brilhantes, jaz o sublime. Impacta e perturba.

Pnêumica estupefaciente diante da corrupção insolúvel da arma na rama e da alma na lama. Pnêumica do espasmo pútrido dentro do humano dizimado humano. 


\section{Patch work p nê u mico}

No seu famoso texto de 1935/36 - A obra de arte na era de sua reprodutibilidade técnica -, Walter Benjamin termina alertando contra a estetização da política (como prática fascista) e propõe uma politização da arte. Em uma tematização um pouco mais adiante da abertura desse texto, quando Benjamin discorre sobre o valor de culto e o valor de exposição, fica declarado que "a produção artística começa com imagens a serviço da magia" Poucas linhas depois, acrescenta que "à medida que as obras de arte se emancipam do seu uso ritual, aumentam as ocasiões para que elas sejam expostas" (Benjamin, 1987, p. 173). Contudo, Ihe parece remanescente um processo elementar de enfrentamento comum entre as sociedades pré-históricas e as contemporâneas no sentido da emoção mobilizadora (com perdão dessa redundância etimológica). Sobre esse aspecto, estimo que valha citar o trecho de fechamento desse item acerca do culto e da exposição:

\footnotetext{
Diante dessa segunda natureza [técnica, tecnologia], que o homem inventou, mas há muito não controla, somos obrigados a aprender, como outrora diante da primeira. Mais uma vez a arte põe-se a serviço desse aprendizado. Isso se aplica, em primeira instância, ao cinema. O filme serve para exercitar o homem nas novas percepções e reações exigidas por um aparelho técnico cujo papel cresce cada vez mais em sua vida cotidiana. Fazer do gigantesco aparelho técnico do nosso tempo o objeto das inervações humanas - essa é a tarefa histórica cuja realização dá ao cinema o seu verdadeiro sentido (Benjamin, 1987, p. 174).
}

Entendo que as "inervações humanas" estão para um olhar sócio-psíquico assim como emoções mobilizadoras amparam um ver pnêumico. Lá se enraízam hermenêuticas para uma pedagogia civilizatória, aqui florescem heurísticas para uma espiritualidade dos espantos imaginativos, inventivos e imersivos. Nos dois movimentos impera o tempo - senhor do cinema com suas linguagens e servo do filme com seus 24 quadros por segundo (Foto 12).

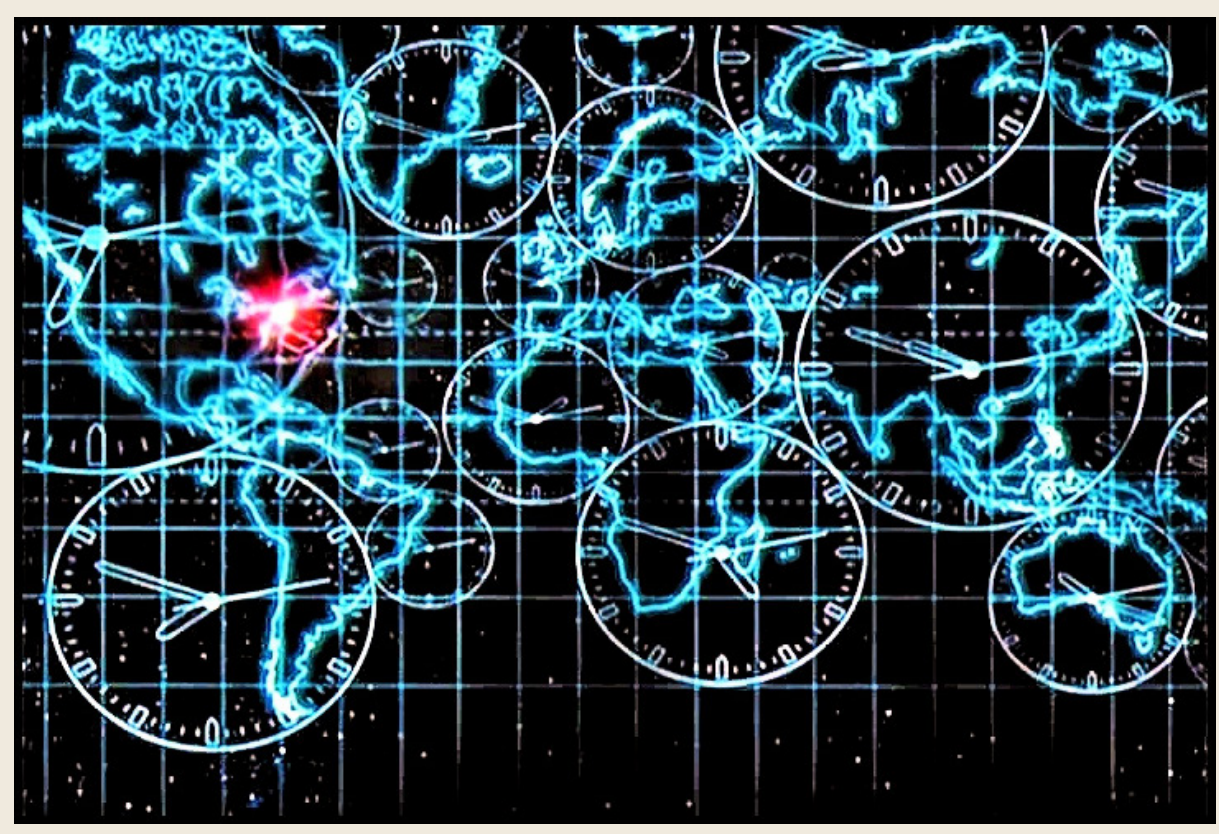

Foto 12 - Vinheta entre os segmentos.

Fonte: Imagem capturada do filme $11^{\prime} 09^{\prime \prime} 01^{\prime}$ (2002). 
Nos retalhos do 11'09"01, o tempo compareceu sempre. Chegou a ser quase um protagonista, como Cronos (sem computar a dúzia de vezes em que retornou como imagem/vinheta, acima reproduzida). E não deixou de fazer uma atuação crucial mais arrematada como Kairós. Recordando: naquele segmento do Irã, é o minuto de silêncio. No da França, é o aniversário de um ano. No do Egito, é a entrevista às $10 \mathrm{~h}$ no day after. No da Bósnia Herzegovina, é o relógio que testemunha uma insônia invencível. No da Burkina Fasso, é o período de pouco mais de uma semana para a divulgação de recompensa pela entrega de Osama bin Laden. No do Reino Unido, é o resgate de outro 11 de setembro, o de 1973. No do México, é a demora da tela escura e a rapidez das imagens das torres. No de Israel, é a fatídica coincidência de atos terroristas no mesmo dia, na mesma hora. No da Índia, é a espinhosa diferença de semanas entre o desaparecimento, a denúncia e o desagravo. No dos Estados Unidos, é o largo deslumbre rebobinado: retro-tempo-real. No do Japão, é o inoportuno que serpenteia desenganos.

Por fim e não menos grave, além de encontrar Cronos e Kairós, indago por Aion. Esse fundaria e se desdobraria naqueles? Possuiria transcendência imanente e subsistente como eterno no enquanto crônico e kairótico dos corpos? Se na materialidade somática, aparece mais Cronos; se na historicidade psíquica, acontece mais Kairós; pergunto: é na inventividade pnêumica que se abastece (ou não) Aion? Pressinto apenas que em 11 de setembro de 2001 a queda das Torres Gêmeas abriu um buraco espiritual para o tempo e suas temporalidades, instalou uma extinção simbólica para o ontem, para o amanhã, para o agora.

Do tempo, no tempo e para o tempo, as perdas com a destruição material e empresarial em nada se igualam às perdas de pessoas, independente de todos os seus predicados. Nos destroços daquela terça-feira repousou caótico o emaranhado passado-e-futuro de gente com idades e vivências díspares. Supondo que em cada vítima radicava e repercutiria um Aion, as intermináveis horas e insuportáveis angústias do 11/9/2001 pulverizaram todo sentido pnêumico genuíno daqueles corpos. Os sobreviventes e a sociedade, desde então, tentam ressignificar a tragédia inominável - uma empreitada precariamente substitutiva posto que dirigida para os mortos ou pelos mortos, jamais dos mortos. As preposições finalista-in-memoriam e de permuta-com-boa-fé não equivalem à genitiva e substancial relação gramático-ôntico-aiônica. Sonhos e saudades são prerrogativas particulares e indelegáveis dos vivos, ainda que dormindo.

Portanto, parece que redunda em mera verborragia o fútil intento de exprimir uma vontade-que-seja concernente a essas mortes. O irreversível delas é absoluto por demais. É preciso exorcizar petulâncias de qualquer ordem a qualquer tempo. Com efeito, hipóteses explicativas ou prospectivas se dissolvem ante o inexorável e o irreparável de cada morrer. Além do choro, da indignação, sobrevive um vazio espelhando o segredo pnêumico daquelas vítimas - arcano corpóreo uma vez mais reatualizando com ênfase na incognoscibilidade plena e última do morrer. Só sobra um sussurro: saudade é sábado sem sonho.

Uma voluntariosa mística para um Aion novaiorquino de 11 de setembro de 2001 quem sabe, reitero, seja sobretudo a constatação da definitiva incapacidade de expressão suficiente. Outrossim, numa insistência irregular, esse Aion talvez seja poetizável nos termos de um pré-socrático: "o tempo [aion] é uma criança que brinca, movendo as pedras do jogo para lá e para cá; governo de criança" (Heráclito, 1999, p. 93). Sim. Aion como pnêumica in-falante, re-creativa, móbile. Medula espermática de eternidade.

Inspirado pelo obscuro pensador de Éfeso e cumprindo o prometido na coleta inicial desses retalhos de uma pnêumica - aqui-e-agora esgarçados e desbotados -, reconheço meu constrangimento ao jogar/brincar na imagem adiante meu jorro de centelhas. Dou uma de criança. Cismo cerzir incompatibilidades. Franjo tristes passamentos. Dobro sem concluir (Fotos 13 e 14). 


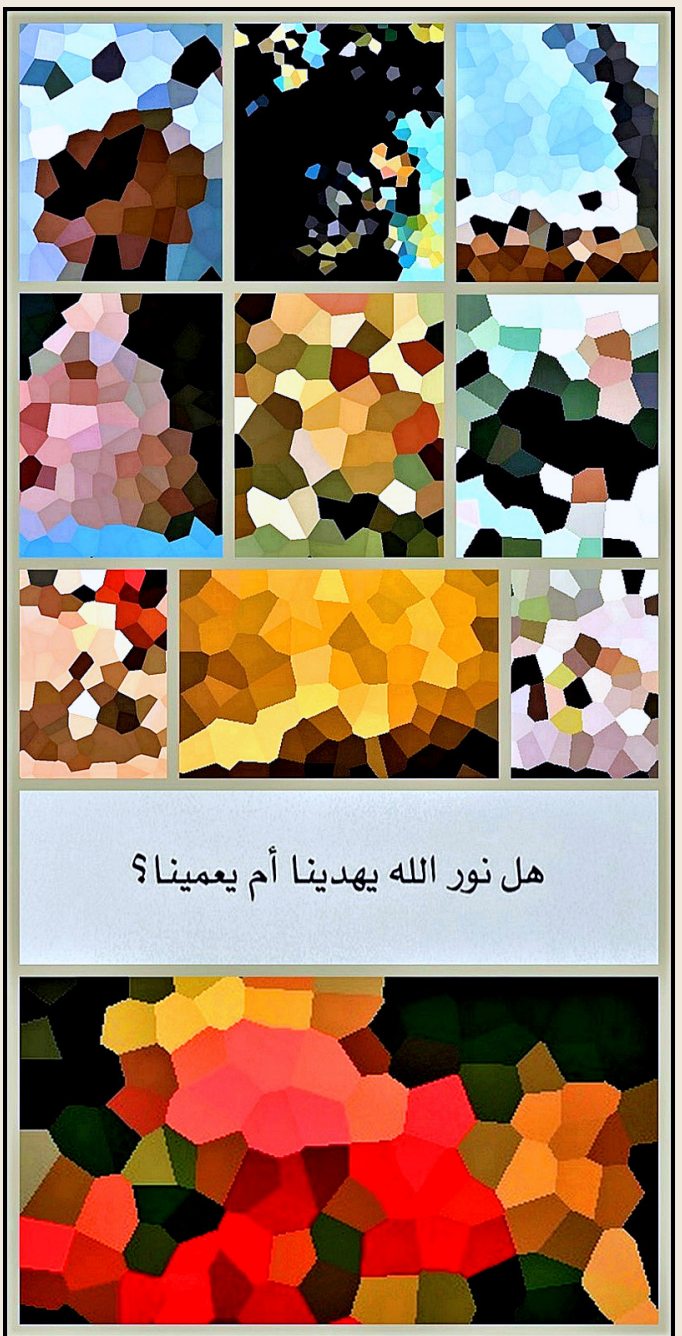

Foto 13 - Patchwork pnêumico. Fonte: Elaborado pelo autor (2021).

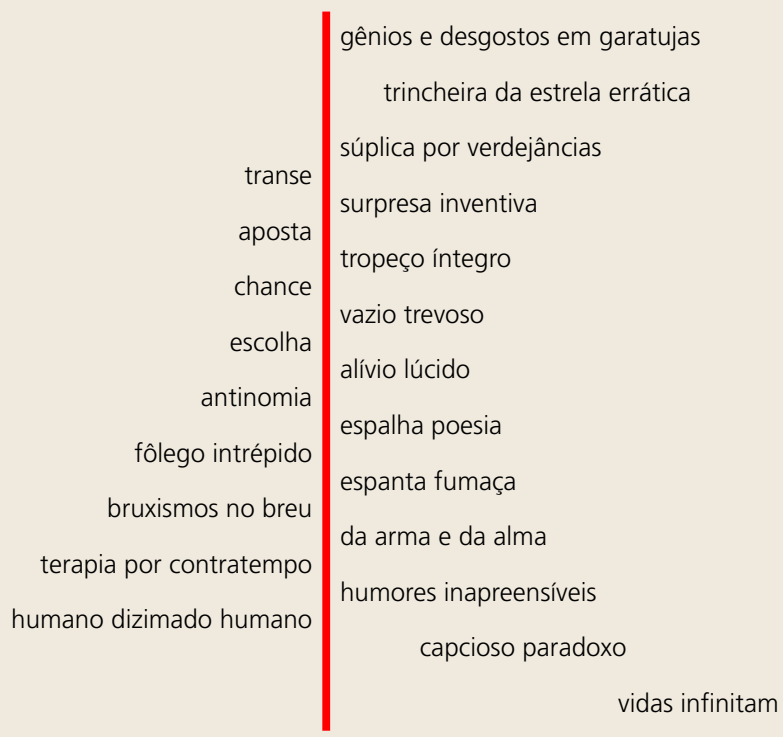

Foto 14 - Retaliações, retículas e reticências.

Fonte: Elaborado pelo autor (2021). 


\section{Referências}

Assis, M. Memórias póstumas de Brás Cubas. São Paulo: Editora Martin Claret, 2002.

Benjamin, W. A obra de arte na era de sua reprodutibilidade técnica. In: Benjamin, W. Magia e técnica, arte e política. Tradução Sergio Paulo Rouanet. São Paulo: Editora Brasiliense, 1987. p. 165-196.

Heráclito. Fragmentos. In: Mileto T. et al. Os Pré-Socráticos. Tradução José Cavalcante de Souza. São Paulo: Editora Nova Cultural, 1999. p. 81-116.

Lima Júnior, J. Corpoética: um passeio pela palavra. Campinas: Texto \& Textura, 2013.

11 de setembro (11'09"01). Direção: Youssef Chahine, Amos Gitaï, Alejandro González, Shohei Imamura, Claude Lelouch, Ken Loach, Samira Makhmalbaf, Mira Nair, Idrissa Ouedraogo, Sean Penn, Danis Tanovic. Produção: Alain Brigand. Inglaterra/França: Galatée Films e Studiocanal, 2002. 1 DVD (128 min), son., color., legendado.

Valery, P. Petite lettre sur les mythes. In: Valery, P. Variété II. Paris: Gallimard, 1930. p. 243-258.

Wittgenstein, L. Tractatus Logico-Philosophicus. Tradução José Arthur Giannotti. São Paulo: Companhia Editora Nacional/USP, 1968.

Como citar este artigo/How to cite this article

Lima Júnior, J. Retalhos de uma pnêumica. Reflexão, v. 46, e215358, 2021. https://doi.org/10.24220/2447-6803v46e202 $1 a 5358$ 